\title{
Evaluasi Peraturan Bupati Banyuwangi Nomor 88 Tahun 2011 (studi pada penutupan lokalisasi prostitusi Padang Bulan di Desa Benelan Kidul Kecamatan Singojuruh Kabupaten Banyuwangi)
}

\author{
Oleh : Alissa Ernawati Adisiswanto \\ Universitas Mochammad Sroedji Jember \\ Jl. Sriwijaya No. 32 Jember 68124 \\ alissaerna@gmail.com
}

\begin{abstract}
ABSTRAK
Penulisan ini berfokus pada evaluasi kebijakan pemerintah yang ditetapkan dalam Peraturan Bupati Banyuwangi Nomor 88 Tahun 2011. Kebijakan ini digunakan sebagai dasar implementasi penutupan lokalisasi prostitusi pada dua belas lokalisasi prostitusi yang ada di wilayah Kabupaten Banyuwangi. Dari sisi output implementasi kebijakan dapat dinyatakan relatif baik, karena mampu menutup dua belas lokalisasi prostitusi yang ada. Pada penutupan lokalisasi prostitusi Padang Bulan yang sudah dilakukan, nampaknya tidak berhasil menghilangkan kegiatan prostitusi didalamnya, meskipun secara faktual mengalami penurunan secara drastis dari sisi pengunjung, jumlah pekerja seks komersial dan mucikarinya. Kegiatan prostitusi ini disebabkan oleh faktor sosial ekonomi. Mucikari yang masih bertahan di lokalisasi prostitusi Padang Bulan adalah mucikari yang berstatus pemilik tanah beserta rumah/bangunan. Penutupan lokalisasi prostitusi memberikan dampak positif dan negatif dari sisi ekonomi, sosial dan kesehatan masyarakat. Penelitian ini bertujuan untuk mendeskripsikan hasil evaluasi kebijakan serta dampak penutupan lokalisasi prostitusi Padang Bulan dari tahun 2014 sampai tahun 2016. Tipe penelitian ini adalah penelitian kualitatif dengan jenis deskriptif. Sasaran penelitiannya adalah pada lokalisasi prostitusi Padang Bulan di Desa Benelan Kidul Kecamatan Singojuruh.
\end{abstract}

Kata kunci : Penutupan lokalisasi prostitusi, Penularan HIV/AIDS, Ouput kebijakan, dan Dampak penutupan.

\section{A. Pendahuluan}

Prostitusi merupakan sebuah masalah sosial yang memberikan stigma negatif bagi masyarakat. serta merupakan masalah sosial yang sulit dikendalikan. Prostitusi dianggap sebagai gejala pathologis karena melanggar norma agama, sosial dan hukum. Poerwadarminta (1998:548) menyatakan "Prostitusi adalah pertukaran hubungan seksual dengan uang atau hadiah sebagai suatu transaksi perdagangan atau pelacuran. Pelacuran adalah perihal menjual diri, dan pelacur berarti wanita tuna susila". Tempat yang menjadi pusat kegiatan prostitusi biasanya disebut lokalisasi prostitusi, tempat inilah yang dianggap sebagai pusat penyebar virus HIV/AIDS sebagai dampak yang ditimbulkan oleh kegiatan pelacuran. Upaya yang dilakukan untuk menghindari akibat-akibat negatif yang ditimbulkan dari kegiatan prostitusi adalah menutup lokalisasi prostitusi.

Pemerintah daerah Kabupaten Banyuwangi adalah pemerintah daerah yang melakukan upaya penanggulangan prostitusi diawali dengan cara penutupan lokalisasi, dengan mengeluarkan Peraturan Bupati Banyuwangi Nomor 88 Tahun 2011 tentang Pencegahan dan Penanggulangan Penyebarluasan Pekerja Seks Komersial (PSK) di kabupaten Banyuwangi sebagai dasar kebijakannya. Di Kabupaten Banyuwangi terdapat 12 
lokalisasi prostitusi. Seluruh lokalisasi menjadi sasaran kebijakan penutupan yang dilakukan secara bertahap.

Sejak dikeluarkannya Peraturan Bupati Banyuwangi Nomor 88 Tahun 2011 penutupan lokalisasi terus dilakukan, hingga terakhir pada April 2014 dilakukan di lokalisasi Padang Bulan yang merupakan lokalisasi prostitusi terbesar di Kabupaten Banyuwangi. Hasil dari implementasi kebijakan yang dilakukan adalah menutup dua belas lokalisasi prostitusi. Akan tetapi di lokalisasi prostitusi Padang Bulan secara kasat mata dapat dilihat masih ada kegiatan prostitusi. Fenomena yang ada di lokalisasi Padang Bulan, penutupan lokalisasi memberikan transformasi kesadaran terhadap tindakan-tindakan individu yang terkait dengan para pelaku prostitusi untuk keluar dari jerat prostitusi, tetapi bagi pelaku prostitusi yang masih menjadi penghuni maupun yang datang ke lokalisasi memunculkan apatisme terhadap hukum dan mencari cara untuk mensiasati tekanan hukum yang dilakukan oleh agen-agen pelaksana di lapangan. Penutupan lokalisasi di Padang Bulan menimbulkan dampak positif dan negatif. Penelitian ini bertujuan untuk mendeskripsikan hasil evaluasi kebijakan yang lebih difokuskan pada lokalisasi prostitusi Padang Bulan serta dampak dari penutupan lokalisasi prostitusi, karena hanya lokalisasi prostitusi Padang Bulan yang nampak masih ada kegiatan prostitusi setelah lokalisasi ini ditutup oleh pemerintah daerah, sehingga dapat dideskripsikan dengan hasil yang lebih baik. Kajian evaluasi dalam penelitian ini akan dibatasi setelah kebijakan ini telah diimplementasikan sehingga menggunakan tipe ex-post evaluation.

\section{B. Kajian Teori}

Peraturan Bupati Banyuwangi Nomor 88 Tahun 2011 adalah kebijakan yang dikeluarkan oleh pemerintah Kabupaten Banyuwangi dengan tujuan tidak ada lagi lokalisasi prostitusi di wilayah Kabupaten Banyuwangi. Mustopadidjaja (2002:15) menyatakan, "Kebijakan publik dibuat dan dikeluarkan adalah diharapkan dapat menjadi solusi dari tujuan kebijakan publik, yakni mengatasi permasalahan yang muncul dalam kegiatan tertentu yang dilakukan oleh instansi pemerintah dalam rangka penyelenggaraan pemerintahan”. James E. Anderson (Winarno, 2007:18) mendefinisikan, "Kebijakan publik sebagai arah tindakan yang mempunyai maksud yang ditetapkan oleh seorang aktor atau sejumlah aktor dalam mengatasi suatu masalah atau suatu persoalan". Dapat disimpulkan bahwa kebijakan publik adalah keputusan atau peraturan yang dibuat oleh pemerintah yang berwenang untuk mengatasi masalah publik dengan harapan kebijakan tersebut akan dicapai dengan baik. Dalam konteks penelitian ini, penutupan lokalisasi prostitusi di Kabupaten Banyuwangi merupakan salah satu bentuk kebijakan publik yang bertujuan untuk tidak ada lagi lokalisasi prostitusi, sehingga diharapkan mampu menghentikan kegiatan prostitusi dan dapat menekan jumlah penderita HIV/AIDS.

Purwanto dan Sulistyastuti (2012:21) mengatakan, "Implementasi intinya adalah kegiatan untuk mendistribusikan keluaran kebijakan (to deliver policy output) yang dilakukan oleh para implementor kepada kelompok sasaran (target group) sebagai upaya untuk mewujudkan kebijakan. Agustino (2014:139) menyatakan bahwa, "Implementasi merupakan suatu proses yang dinamis, dimana pelaksana kebijakan melakukan suatu aktivitas atau kegiatan, sehingga pada akhirnya akan mendapatkan suatu hasil yang sesuai dengan tujuan atau sasaran kebijakan itu sendiri”. Sedangkan Lester dan Stewart (Agustino 2014:186), "Evaluasi ditujukan untuk melihat sebagian-sebagian kegagalan suatu kebijakan dan untuk mengetahui apakah kebijakan yang telah dirumuskan dan dilaksanakan dapat menghasilkan dampak yang diinginkan". 
Evaluasi kebijakan dalam menghasilkan informasi, dalam penelitian ini menggunakan teori yang dikemukakan oleh William N. Dunn. Kriteria evaluasi kebijakan menurut Dunn (2003:610) adalah :

\begin{tabular}{|c|c|c|}
\hline TIPE KRITERIA & PERTANYAAN & ILUSTRASI \\
\hline Efektivitas & Apakah hasil yang diinginkan telah dicapai? & Unit Pelayanan \\
\hline Efisiensi & $\begin{array}{l}\text { Seberapa banyak usaha diperlukan untuk mencapai hasil } \\
\text { yang diinginkan? }\end{array}$ & $\begin{array}{l}\text { Unit biaya } \\
\text { Manfaat bersih } \\
\text { Rasio biaya-manfaat }\end{array}$ \\
\hline Kecukupan & $\begin{array}{l}\text { Seberapa jauh pencapaian hasil yang diinginkan } \\
\text { memecahkan masalah? }\end{array}$ & $\begin{array}{l}\text { Biaya tetap } \\
\text { (masalah tipe I) } \\
\text { Efektifitas tetap } \\
\text { (masalah tipe II) }\end{array}$ \\
\hline Pemerataan & $\begin{array}{l}\text { Apakah biaya dan manfaat didistribusikan dengan merata } \\
\text { kepada kelompok-kelompok yang berbeda? }\end{array}$ & $\begin{array}{l}\text { Kriteria pareto } \\
\text { Kriteria kaldor-Hicks } \\
\text { Kriteria rawls }\end{array}$ \\
\hline Responsivitas & $\begin{array}{l}\text { Apakah hasil kebijakan memuaskan kebutuhan, preferensi } \\
\text { atau nilai kelompok-kelompok tertentu? }\end{array}$ & $\begin{array}{l}\text { Konsistensi dengan survei } \\
\text { warga negara }\end{array}$ \\
\hline Ketepatan & $\begin{array}{l}\text { Apakah hasil (tujuan) yang diinginkan benar-benar berguna } \\
\text { atau bernilai? }\end{array}$ & $\begin{array}{l}\text { Program publik harus merata } \\
\text { dan efisien }\end{array}$ \\
\hline
\end{tabular}

Sumber : William N. Dunn (2003:610)

Kriteria evaluasi tersebut yang akan digunakan dalam evaluasi penutupan lokalisasi prostitusi di Padang Bulan serta dampak yang diakibatkannya.

\section{B. Metode Penelitian}

Tipe penelitian ini adalah penelitian kualitatif dengan jenis deskriptif. Penelitian kualitatif dengan jenis deskriptif dalam penelitian ini adalah peneliti berusaha mengungkapkan apa adanya mengenai fakta yang ada di lapangan. Data yang berhasil didapat dari lapangan adalah kata-kata hasil wawancara, gambar serta angka-angka. Data yang berupa angka dalam penelitian ini penggunaannya hanya sebatas sebagai penjelas dan penegas dalam analisis data primer.

Lokasi penelitian yang dipilih di kabupaten Banyuwangi dengan sasaran penelitian di lokalisasi prostitusi Padang Bulan desa Benelan Kidul kecamatan Singojuruh. Sasaran penelitian ini menarik untuk dipilih oleh peneliti karena beberapa hal diantaranya adalah selain merupakan lokalisasi prostitusi terbesar, fenomena fakta pembangkangan tampak masih sangat kuat di lokalisasi prostitusi yang telah dinyatakan tutup oleh pemerintah daerah. Lokalisasi prostitusi ini masih menerima PSK pendatang dan sampai saat ini masih ada praktek prostitusi, meskipun jumlahnya jauh berkurang. Fokus penelitian ini adalah evaluasi penutupan lokalisasi prostitusi pada lokalisasi prostitusi Padang Bulan berdasarkan Peraturan Bupati Banyuwangi Nomor 88 Tahun 2011 dan dampak yang ditimbulkan dari kebijakan tersebut. Dalam penelitian yang dilakukan, cara untuk mendapatkan data adalah melalui observasi, wawancara dan dokumentasi. Dalam penentuan informan peneliti menggunakan metode snowball.

Data yang diperoleh untuk kepentingan penelitian ini, yang berupa data primer dan data sekunder, oleh peneliti akan disusun terlebih dahulu kemudian disajikan, dilanjutkan 
dengan melakukan analisa data dengan pendekatan kualitatif yang berbentuk pemaparan, diteruskan dengan dianalisis kemudian dinarasikan yang tidak menyimpang dari masalah penelitian. Model analisis data interaktif (interactive model of analysis) dari Miles dan Huberman, 1992 digunakan dalam penelitian ini untuk menganalisa data. Pelaksanaan teknik analisa data, peneliti telah memulainya sejak memasuki lokasi penelitian. Karena pada prinsipnya, analisis data penelitian kualitatif dilakukan selama proses penelitian. Teknik pemeriksaan keabsahan data dilakukan dengan triangulasi hasil wawancara dengan informan yang berbeda, hasil wawancara dengan kondisi obyek (triangulasi data), sehingga pengumpulan data dan triangulasi melibatkan observasi, wawancara dan dokumentasi. Selain itu peneliti juga melakukan pemeriksaan tambahan dengan meminta orang lain sejawat yang kompeten dan mempunyai banyak pengalaman dalam melakukan penelitian lapangan untuk membaca kembali data-data yang ada. Misalnya peneliti juga melakukan diskusi dengan seorang aktivis perempuan yang mempunyai perhatian untuk mengamati perempuan pelacur dan kehidupan prostitusi, karena seorang pembaca dari luar seringkali dapat menangkap aspek lingkungan penelitian yang lebih halus dan tidak terlihat oleh peneliti.

\section{Hasil Penelitian}

Jumlah penderita HIV/AIDS di Kabupaten Banyuwangi setiap tahunnya terus meningkat, ini yang menjadi salah satu pertimbangan dikeluarkannya Peraturan Bupati Banyuwangi Nomor 88 Tahun 2011, yang kemudian diimplementasikan dengan penutupan di dua belas lokalisasi prostitusi yang ada di Kabupaten Banyuwangi.

Lokalisasi prostitusi Padang Bulan berada di perkampungan yang tidak jauh dengan pemukiman warga, perkampungan itu mirip perkampungan biasa yang memiliki sejumlah kepala keluarga. Keberadaan lokalisasi Padang Bulan tidak memiliki Surat Keputusan Bupati (SK Bupati), tetapi dengan adanya penyuluhan, sosialisasi HIV dan klinik kesehatan seolaholah keberadaan lokalisasi prostitusi ini nampak legal, padahal tujuan yang sebenarnya untuk mencegah menularnya HIV/AIDS. PSK yang berada di lokalisasi Padang Bulan lebih banyak yang berasal dari luar kabupaten Banyuwangi. Dari hasil pendataan yang dilakukan pada tahun 2014, terdapat 143 orang PSK, yang berasal dari Banyuwangi 42 orang atau 29,4\% dari jumlah keseluruhan PSK yang ada di lokalisasi. Selebihnya, 101 orang atau 70,6\% berasal dari luar kabupaten Banyuwangi. Dalam penanganan PSK yang berasal dari luar Kabupaten Banyuwangi, camat Singojuruh menjelaskan bahwa, "Asal PSK di Padang Bulan itu paling banyak dari luar Banyuwangi, dan sudah kita pulangkan. rata-rata usia PSK adalah usia produktif yakni usia dimana manusia mampu bekerja. Dalam usia produktif ini biasanya wanita masih kelihatan cantik dan menarik, sehingga mudah untuk mendapatkan pelanggan". Setelah lokalisasi dinyatakan tutup oleh pemerintah daerah, membawa pengaruh antara lain lingkungan disekitar lokalisasi nampak sepi, tidak nampak secara jelas PSK cangkrukan di warung-warung sekitar lokalisasi, tidak ramai kendaraan yang lalu lalang dan tempat parkir yang nampak kosong. Dengan berkurangnya jumlah PSK yang ada membuat jumlah pengunjungpun berkurang, hal ini juga mengurangi pendapatan masyarakat sekitar yang mengandalkan pendapatannya dari keberadaan lokalisasi karena konsumennya adalah sebagian besar penghuni dan pengunjung lokalisasi.

Dari hasil wawancara menunjukkan bahwa keberadaan lokalisasi prostitusi pada hakikatnya memiliki beberapa pihak yang berkepentingan di dalamnya. PSK dan mucikari memerlukan keberadaan lokalisasi sebagai tempat bekerja agar mendapatkan uang untuk memenuhi kebutuhan hidupnya. Laki-laki sebagai pelanggan bisa dengan mudah bertemu dengan PSK di lokalisasi dan sebaliknya. PSK dan pelanggan saling membutuhkan dan saling menguntungkan. Di lokalisasi, mucikari maupun PSK, laki-laki sebagai pelanggan dan pelaku lain saling membutuhkan untuk pemenuhan kebutuhannya. Pelaku lain adalah para 
preman, pemilik wisma, calo PSK, petugas keamanan, tukang parkir, tukang ojek serta penjual barang ataupun jasa yang memperoleh pendapatan dari keberadaan lokalisasi. Masyarakat yang berada di sekitar lokalisasi yang berjualan nasi maupun yang membuka warung dan menyediakan kebutuhan hidup sehari-hari mendapatkan penghasilan dari keberadaan lokalisasi, karena sebagian besar konsumennya adalah para pengunjung, mucikari dan PSK. Keberadaan lokalisasi mampu menghidupkan perputaran roda ekonomi masyarakat sekitar. Sedangkan bagi Komisi Penanggulangan AIDS dengan adanya lokalisasi lebih mudah melakukan penangananan, pendampingan dan pemantauan kepada ODHA dan para PSK yang rawan sebagai penyebar virus HIV/AIDS.

Output implementasi Perda penutupan lokalisasi prostitusi di wilayah Kabupaten Banyuwangi telah menghasilkan kinerja yang relatif baik meskipun belum efektif, karena masih nampak kegiatan prostitusi yang dilakukan secara sembunyi sembunyi di lokalisasi prostitusi Padang Bulan. Pada evaluasi kebijakan penutupan lokalisasi prostitusi Padang Bulan, peneliti menggunakan tolok ukur atau kriteria pendapat Dunn, yang dapat disederhanakan dalam tabel berikut :

Evaluasi Peraturan Bupati Banyuwangi Nomor 88 Tahun 2011

\begin{tabular}{|c|c|c|c|c|}
\hline No & Kriteria & Seharusnya & Kenyataan & Kategori \\
\hline 1 & Efektivitas & $\begin{array}{l}\text { Tujuan kebijakan adalah } \\
\text { tutupnya lokalisasi prostitusi }\end{array}$ & $\begin{array}{l}\text { Lokalisasi masih buka dan ada } \\
\text { kegiatan prostitusi di dalamnya, } \\
\text { tetapi berkurang (tidak seramai } \\
\text { sebelum dinyatakan ditutup) }\end{array}$ & Kurang efektif \\
\hline 2 & Efisien & $\begin{array}{l}\text { Dengan biaya sesuai yang } \\
\text { ditetapkan tujuan kebijakan } \\
\text { tercapai }\end{array}$ & $\begin{array}{l}\text { Dengan telah dikeluarkan } \\
\text { usaha dan biaya yang besar, } \\
\text { tetapi tujuan kebijakan tidak } \\
\text { tercapai (kurang efektif) }\end{array}$ & Tidak Efisien \\
\hline 3 & Kecukupan & $\begin{array}{l}\text { - Dengan biaya sesuai yang } \\
\text { ditetapkan tujuan kebijakan } \\
\text { tercapai } \\
\text { - Dengan biaya yang lebih } \\
\text { rendah dapat mencapai tujuan } \\
\text { kebijakan }\end{array}$ & $\begin{array}{l}\text { Dengan biaya yang sudah } \\
\text { ditetapkan, tujuan kebijakan } \\
\text { tidak tercapai (kurang efektif). } \\
\text { - Menimbulkan prostitusi liar di } \\
\text { tempat lain } \\
\text { - Tidak mampu menekan } \\
\text { penyebaran virus HIV/AIDS) }\end{array}$ & $\begin{array}{l}\text { Tidak memenuhi } \\
\text { kriteria } \\
\text { kecukupan }\end{array}$ \\
\hline 4 & Pemerataan & $\begin{array}{l}\text { Penutupan lokalisasi membawa } \\
\text { manfaat dan dirasakan oleh } \\
\text { seluruh lapisan masyarakat, } \\
\text { termasuk mantan PSK dan } \\
\text { mantan mucikari }\end{array}$ & $\begin{array}{l}\text { PSK dan mucikari serta } \\
\text { masyarakat sekitar merasa } \\
\text { dengan penutupan lokalisasi } \\
\text { membuat penghasilannya } \\
\text { sangat berkurang dan sulit } \\
\text { untuk mencukupi kebutuhan } \\
\text { hidupnya }\end{array}$ & $\begin{array}{l}\text { Tidak memenuhi } \\
\text { kriteria } \\
\text { pemerataan }\end{array}$ \\
\hline 5 & Responsivitas & $\begin{array}{l}\text { - Ada respon dari masyarakat } \\
\text {-Ada respon dari PSK dan } \\
\text { mucikari }\end{array}$ & $\begin{array}{l}\text { - Ada respon dari masyarakat } \\
\text { untuk mendukung penutupan } \\
\text { lokalisasi } \\
\text { - Pprogram pelatihan } \\
\text { keterampilan bagi mucikari dan } \\
\text { PSK, yang diberikan sebagai } \\
\text { alternatif pekerjaan yang lebih } \\
\text { baik, mendapat respon dari } \\
\text { PSK dan mucikari, terbukti } \\
\text { dengan mereka mengikuti } \\
\text { pelatihan tersebut dan } \\
\text { kemudian ada dari mereka yang } \\
\text { beralih profesi }\end{array}$ & $\begin{array}{l}\text { Memenuhi } \\
\text { kriteria } \\
\text { responsivitas }\end{array}$ \\
\hline
\end{tabular}




\begin{tabular}{|l|l|l|l|l|}
\hline 6 & Ketepatan & $\begin{array}{l}\text { Substansi menutup semua } \\
\text { lokalisasi prostitusi, dan tidak } \\
\text { ada lagi kegiatan prostitusi } \\
\text { didalamnya }\end{array}$ & $\begin{array}{c}\text { Masih ada kegiatan prostitusi di } \\
\text { lokalisasi yang sudah ditutup } \\
\text { oleh pemerintah daerah }\end{array}$ & $\begin{array}{l}\text { Kurang } \\
\text { memenuhi } \\
\text { kriteria ketepatan }\end{array}$ \\
\hline
\end{tabular}

Sumber data : Hasil penelitian diolah, tahun 2016

Dari kriteria evaluasi kebijakan yang digunakan dalam penelitian ini dapat dijelaskan bahwa, penutupan lokalisasi yang dilakukan di Padang Bulan nampak kurang efektif karena hasil yang dicapai tidak sesuai dengan tujuan yang telah ditentukan lebih awal, melalui observasi dapat dilihat secara kasat mata bahwa prostitusi yang berada di lokalisasi Padang Bulan masih tetap ada, dengan masih ada PSK dan mucikari yang tinggal serta masih adanya kegiatan prostitusi.

Dari sisi efisiensi terlihat bahwa penutupan lokalisasi prostitusi Padang Bulan tidak efisien, karena banyak usaha yang dilakukan dengan banyaknya keterlibatan personil Satuan Kerja Perangkat Daerah serta TNI dan Polri, juga besarnya biaya yang telah dikeluarkan, tetapi hasilnya kurang efektif, karena kebijakan penutupan lokalisasi ini hanya mampu mengurangi PSK dan mucikari serta kegiatan prostitusi, belum mampu menghapus kegiatan prostitusi secara total..

Dari kriteria kecukupan berdasarkan tipe I dan tipe II, kebijakan diharapkan dapat mencapai tujuan yang diinginkan semaksimal mungkin dengan biaya yang seminimal mungkin. Pada penutupan lokalisasi Padang Bulan kurang memenuhi kriteria kecukupan pada masalah tipe I dan tipe II karena usaha dan biaya yang dikeluarkan tidak sedikit tetapi hasil yang dicapai kurang efektif, yakni tidak mampu meniadakan kegiatan prostitusi di Padang Bulan.

Berkenaan dengan sisi pemerataan dalam penutupan lokalisasi prostitusi Padang Bulan, manfaat dari penutupan lokalisasi belum secara merata dirasakan. PSK dan mucikari merasa kehilangan pekerjaannya sebagai sarana mendapatkan uang untuk memenuhi kebutuhan hidupnya, dan masyarakat sekitar lokalisasi yang selama ini menggantungkan penghasilannya pada keberadaan lokalisasi merasa berkurangnya pendapatan mereka.

Dari kriteria responsivitas menunjukkan bahwa penutupan lokalisasi telah memenuhi kriteria responsivitas, karena tanggapan yang telah diberikan oleh masyarakat pada umumnya, kususnya organisasi keagamaan juga organisasi kemasyarakatan serta tokoh agama dan tokoh masyarakat yang mendukung penutupan lokalisasi sebagai wujud penolakan terhadap kegiatan prostitusi yang dianggap sebagai kegiatan yang bertentangan dengan norma agama dan norma kemasyarakatan. Dari pihak sasaran kebijakan yaitu PSK dan mucikari juga memberikan tanggapan, yakni dengan munculnya protes keras mengiringi penutupan lokalisasi prostitusi melalui demonstrasi dan upaya negosiasi untuk mencegah pelaksanaannya, hal ini menunjukkan animo dan dorongan bertahan para pelaku dan sebagian pegiat prostitusi yang tinggi. Meskipun pada akhirnya demonstrasi besar-besaran tidak dapat mengubah pemerintah untuk tetap menutup lokalisasi prostitusi, namun dampak dari penolakan itu termanivestasi dengan cepatnya pembangkangan pada kebijakan melalui menggeliatnya kembali praktek prostitusi di lokalisasi prostitusi Padang Bulan.

Dalam kriteria ketepatan, penutupan lokalisasi Padang Bulan tidak memenuhi kriteria ketepatan, karena kebijakan ini merujuk pada tujuan program pada Pasal 2 ayat 1 dan ayat 2 yang menjelaskan tentang maksud dan tujuannya, yakni maksud ditetapkannya adalah memberikan landasan hukum terhadap proses pengentasan Penyandang Masalah Kesejahteraan Sosial (PMKS) di Kabupaten Banyuwangi, dengan tujuan pencegahan dan penanggulangan Pekerja Seks Komersial (PSK) adalah mengurangi peredaran penyebaran penyakit HIV/AIDS dan penyakit masyarakat lainnya, sasaran pencegahan dan penanggulangan adalah untuk berkurangnya jumlah PSK dan lokalisasi. Hal ini berarti bukan untuk penutupan lokalisasi prostitusi dan seharusnya mucikari tidak termasuk dalam sasaran kebijakan, karena mucikari bukan Penyandang Masalah Kesejahteraan Sosial (PMKS). 
Pelaksanaan kebijakan penutupan lokalisasi prostitusi di Padang Bulan yang dilakukan oleh pemerintah daerah membawa dampak, baik secara positif maupun negatif. Dampak yang timbul antara lain adalah:

a. Dampak Sosial

Dampak positif, mampu menghentikan pengaruh moral negatif kepada generasi muda yang sering melihat hal-hal negatif dari kehidupan di lokalisasi, seperti pesta minuman keras, judi dan sikap serta kata-kata yang kurang baik. Dampak negatif adalah tidak mampu menghentikan transaksi prostitusi secara total dan menyeluruh justru transaksi prostitusi dilakukan sembunyi-sembunyi di eks lokalisasi.

b. Dampak kesehatan masyarakat

Dampak positif adalah mampu mengurangi transaksi prostitusi dan minuman keras, Dampak negatif adalah di lokalisasi keberadaan PSK dan mucikari serta kegiatan prostitusi banyak berkurang, tetapi menimbulkan banyak tempat prostitusi liar, hal ini menyebabkan jumlah PSK yang terdeteksi virus HIV/AIDS tidak dapat diketahui keberadaannya karena mereka sudah menyebar kemana-mana serta tidak bisa ditangani secara intensif pengobatan dan pendampingannya, sedangkan bagi PSK yang kembali melakukan kegiatan prostitusi di eks lokalisasi Padang Bulan ini juga tidak dapat dideteksi kesehatannya, karena sejak lokalisasi ini dinyatakan ditutup oleh pemerintah daerah, otomatis pelayanan kesehatan di lokalisasi bagi para PSK sudah tidak ada lagi.

\section{c. Dampak ekonomi}

Dampak negatif yang muncul adalah membuat masyarakat sekitar merasa menurun dan berkurangnya pendapatan mereka, sedangkan bagi para PSK sendiri penutupan lokalisasi ini dirasa sebagai hal yang akan menyulitkan dirinya untuk memenuhi kebutuhan hidup, sedangkan dampak positif adalah mampu membuat beberapa warga eks lokalisasi berwiraswasta dan beralih profesi. Muncul sikap berwiraswasta sebagai upaya alih profesi dari para eks mucikari dan PSK.

Membahas isi kebijakan dalam Peraturan Bupati Banyuwangi Nomor 88 Tahun 2011 tentang Pencegahan dan Penanggulangan Penyebarluasan Pekerja Seks Komersial (PSK) di Kabupaten Banyuwangi, pada pasal 2 ayat 1 disebutkan maksud ditetapkannya peraturan bupati ini adalah memberikan landasan hukum terhadap proses pengentasan Penyandang Masalah Kesejahteraan Sosial (PMKS). Kebijakan ini kurang spesifik mengarah pada penutupan lokalisasi prostitusi dan pelarangan terhadap kegiatan prostitusi di lokalisasi yang sudah dinyatakan ditutup oleh pemerintah. Dari hasil penelitian menunujukkan bahwa isi dalam kebijakan Peraturan Bupati Banyuwangi Nomor 88 Tahun 2011 kurang tepat apabila digunakan untuk penutupan lokalisasi prostitusi, karena maksud ditetapkannya tidak secara jelas diperuntukkan penutupan lokalisasi dan tidak memuat tentang larangan kepada PSK dan mucikari mengadakan kegiatan prostitusi pada lokalisasi yang sudah dinyatakan tutup, serta tidak memuat larangan dan sanksi bagi pelanggar kebijakan.

Dari hasil penelitian terlihat implementasi dari kebijakan tersebut adalah dengan menutup seluruh lokalisasi prostitusi yang ada di kabupaten Banyuwangi karena lokalisasi dianggap sebagai sarang penyebaran virus HIV/AIDS. Penutupan lokalisasi prostitusi membawa hasil yang positif, yakni mampu menutup lokalisasi prostitusi yang ada tetapi masih terlihat kurang efektif karena masih ada satu lokalisasi prostitusi yang masih ada kegiatan prostitusi di dalamnya, yaitu lokalisasi prostitusi Padang Bulan di Desa Benelan Kidul Kecamatan Singojuruh.

Pembangkangan yang terjadi berkaitan dengan pasca pelaksanaan penutupan lokalisasi ini adalah beberapa PSK yang masih tinggal ini menyadari bahwa razia harus dihindari, dengan cara apabila ada informasi akan dilakukan razia mereka memilih untuk keluar sementara dari lokalisasi prostitusi tersebut untuk menyingkir sampai kemudian diterima berita bahwa keadaan sudah "aman" sehingga mereka bisa kembali berada di 
lokalisasi prostitusi tersebut. Inilah yang disebut upaya pembangkangan yang terus menerus dilakukan. Untuk mendapatkan informasi bahwa akan dilakukan razia biasanya dilakukan oleh "informan" yang sudah diketahui bersama oleh PSK dan mucikari, sebagai imbalannya para PSK ini membayar iuran secara rutin.

Menurut hasil wawancara dengan beberapa informan pada penelitian ini, pada saat lokalisasi prostitusi belum ditutup, rutin dilakukan pembinaan terhadap para PSK dan mucikari sebagai upaya pemberdayaan. Biasanya program pemberdayaan ini berupa pelatihan ketrampilan untuk wanita (seperti menjahit, memasak, salon, dan membuat kerajinan tangan). Sungguhpun demikian, semua program penambahan ketrampilan dianggap satu hal yang naif dan hanya buang-buang tenaga dan uang saja, karena para PSK tidak memiliki minat yang dapat mengarahkan dirinya untuk lebih mendalami ketrampilan yang telah diberikan tersebut. Para prostitute itu mengikuti pelatihan hanya karena harus patuh pada pelaksanaan kegiatan yang sudah terjadwal sebagai bentuk rutinitas yang wajib untuk diikuti sebagai penghuni lokalisasi prostitusi. Sehingga program kerja pemberdayaan para perempuan PSK dan mucikari yang telah dilakukan sebelumnya menjadi suatu yang kurang berperan untuk merubah status perempuan PSK dan mucikari menjadi pelaku usaha mandiri sektor bisnis normal.

Peraturan Bupati Banyuwangi Nomor 88 Tahun 2011 yang digunakan sebagai dasar penutupan pada lokalisasi prostitusi Padang Bulan terlihat kurang efektif dalam rangka membasmi praktek prostitusi, karena dengan penutupan lokalisasi prostitusi membuat keberadaan PSK terdistribusi dengan merata di tempat-tempat strategis dan memunculkan banyak tempat prostitusi liar, disamping itu masih ada PSK yang kembali ke lokalisasi Padang Bulan untuk tetap melakukan praktek prostitusi secara sembunyi-sembunyi, karena masih ada wisma yang buka dan menerima PSK yang datang. Hal ini disebabkan karena mucikari adalah penduduk asli dan pemilik wisma, yang bersedia keluar dari lokalisasi apabila tanah dan rumahnya dibeli oleh pemerintah daerah.

\section{E. Kesimpulan}

Output dari Evaluasi Peraturan Bupati Banyuwangi Nomor 88 Tahun 2011 tentang Pencegahan dan Penanggulangan Penyebarluasan Pekerja Seks Komersial (PSK) yang digunakan sebagai dasar kebijakan pada penutupan lokalisasi prostitusi Padang Bulan adalah:

1. Kurang efektif, lokalisasi masih buka dan ada kegiatan prostitusi di dalamnya, tetapi berkurang (tidak seramai sebelum dinyatakan ditutup)

2. Tidak Efisien, dengan telah dikeluarkan usaha dan biaya yang besar, tetapi tujuan kebijakan tidak tercapai (kurang efektif)

3. Tidak memenuhi kriteria kecukupan, dengan biaya yang sudah ditetapkan, tujuan kebijakan tidak tercapai (kurang efektif, menimbulkan prostitusi liar di tempat lain, tidak mampu menekan penyebaran virus HIV/AIDS)

4. Tidak memenuhi kriteria pemerataan, PSK dan mucikari serta masyarakat sekitar merasa dengan penutupan lokalisasi membuat penghasilannya sangat berkurang dan sulit untuk mencukupi kebutuhan hidupnya

5. Memenuhi kriteria responsivitas, ada respon dari masyarakat untuk mendukung penutupan lokalisasi, program pelatihan keterampilan bagi mucikari dan PSK, yang diberikan sebagai alternatif pekerjaan yang lebih baik, mendapat respon dari PSK dan mucikari, terbukti dengan mereka mengikuti pelatihan tersebut dan kemudian ada dari mereka yang beralih profesi

6. Kurang memenuhi kriteria ketepatan, penutupan lokalisasi Padang Bulan tersendat sendat 
Pelaksanaan kebijakan penutupan lokalisasi prostitusi di Padang Bulan yang dilakukan oleh pemerintah daerah membawa dampak, baik secara positif maupun negatif. Dampak yang timbul antara lain adalah:

a. Dampak Sosial

Dampak positif, mampu menghentikan pengaruh moral negatif kepada generasi muda yang sering melihat hal-hal negatif dari kehidupan di lokalisasi, seperti pesta minuman keras, judi dan sikap serta kata-kata yang kurang baik. Dampak negatif adalah tidak mampu menghentikan transaksi prostitusi secara total dan menyeluruh justru transaksi prostitusi dilakukan sembunyi-sembunyi di eks lokalisasi.

b. Dampak kesehatan masyarakat

Dampak positif adalah mampu mengurangi transaksi prostitusi dan minuman keras, Dampak negatif adalah di lokalisasi keberadaan PSK dan mucikari serta kegiatan prostitusi banyak berkurang, tetapi menimbulkan banyak tempat prostitusi liar, hal ini menyebabkan jumlah PSK yang terdeteksi virus HIV/AIDS tidak dapat diketahui keberadaannya karena mereka sudah menyebar kemana-mana serta tidak bisa ditangani secara intensif pengobatan dan pendampingannya, sedangkan bagi PSK yang kembali melakukan kegiatan prostitusi di eks lokalisasi Padang Bulan ini juga tidak dapat dideteksi kesehatannya, karena sejak lokalisasi ini dinyatakan ditutup oleh pemerintah daerah, otomatis pelayanan kesehatan di lokalisasi bagi para PSK sudah tidak ada lagi.

c. Dampak ekonomi

Dampak negatif yang muncul adalah membuat masyarakat sekitar merasa menurun dan berkurangnya pendapatan mereka, sedangkan bagi para PSK sendiri penutupan lokalisasi ini dirasa sebagai hal yang akan menyulitkan dirinya untuk memenuhi kebutuhan hidup, sedangkan dampak positif adalah mampu membuat beberapa warga eks lokalisasi berwiraswasta dan beralih profesi. Muncul sikap berwiraswasta sebagai upaya alih profesi dari para eks mucikari dan PSK.

\section{F. Saran}

Saran yang diberikan adalah :

1. Melibatkan stakeholders yang berkepentingan secara langsung dengan penutupan lokalisasi dari awal pembuatan kebijakan sampai evaluasi kebijakan dilaksanakan.

2. Membuat kebijakan yang isinya dengan jelas ditujukan untuk penutupan lokalisasi prostitusi.

3. Peraturan Bupati Nomor 88 Tahun 2011 adalah kebijakan regulatif, sehingga perlu melibatkan sasaran kebijakan dalam pelaksanaannya

4. Melakukan evaluasi setelah pelaksanaan kebijakan, untuk mengetahui efektivitas kebijakan

Disamping beberapa hal tersebut, melakukan penguatan di sektor ekonomi, sosial, dan keagamaan dari para PSK dan mucikari juga merupakan jalan keluar yang tepat. Akhirnya para PSK dan mucikari akan menyadari bahwa ada pilihan pekerjaan lain yang lebih baik untuk mendapatkan uang dalam memenuhi kebutuhan hidupnya dan keluarganya. 


\section{DAFTAR PUSTAKA}

\section{Buku}

Agustino, Leo. 2014. Dasar-dasar Kebijakan Publik. Bandung : ALFABETA.

Dunn, William N. 2003. Pengantar Analisis kebijakan Publik. Yogyakarta: UGM Press

Mustopadidjaja. 2002. Manajemen Proses Kebijakan Publik: Formulasi, Implementasi dan Evaluasi Kinerja. Jakarta : LAN.

Purwanto, Irwan Agus dan Dyah Ratih Sulistyastuti. 2012. Implementasi Kebijakan Publik: Konsep dan Aplikasinya di Indonesia. Yogyakarta : Gava Media.

Poerwardarminta, WJS. 1998. Kamus Umum Bahasa Indonesia. Jakarta: PN Balai Pustaka.

Winarno, Budi. 2007. Kebijakan Publik Teori dan Proses. Yogyakarta : Media Pressindo

\section{Peraturan Perundang-undangan}

Peraturan Bupati Banyuwangi Nomor 88 Tahun 2011 tentang pencegahan dan penanggulangan penyebarluasan Pekerja Seks Komersial (PSK) di kabupaten Banyuwangi. 